\title{
PERENCANAAN KAPASITAS TERMINAL GENERAL CARGO DENGAN PENDEKATAN SISTEM DINAMIK
}

\author{
Rakhmad Maulidi ${ }^{1)}$, Erma Suryani ${ }^{2)}$ \\ ${ }^{1}$ Jurusan Teknik Informatika, STIKI Malang \\ Jl. Raya Tidar 100, Kota Malang, 65146 \\ Telp: (0341) 560823, Fax: (0341) 562525 \\ ${ }^{2}$ Jurusan Sistem Informasi, Fakultas Teknologi Informasi, Institut Teknologi Sepuluh Nopember \\ Kampus Keputih, Sukolio Surabaya 60111 \\ Telp: (031) 5999944, Fax: (031) 5964965 \\ E-mail: maulidi@stiki.ac.id
}

\begin{abstract}
Characteristics of Indonesia, which dominated by the sea and is the world's trade lanes, making the sea transportation serve as the primary option in shipping cargo. Estimating the number of cargo demand is essential as the basis in determining the capacity in order to meet demand. In this study developed a model of general cargo Stevedoring services at the Port of Tanjung Perak were able to estimate the amount of demand and capacity planning of loading and unloading in accordance with the strategy of capacity planning with the systems dynamic approach. The results of this study indicate that the combination of productivity and lead time can be used as a basis for decision making in capacity planning and system dynamic model can be used to forecast the demand and create flexible scenarios for capacity planning
\end{abstract}

\section{Abstrak}

Karaktiristik wilayah Indonesia yang didominisi oleh laut dan merupakan jalur perdagangan dunia, menjadikan transporasi laut dijadikan sebagai pilihan utama dalam pengiriman kargo. Memperkirakan jumlah permintaan kargo merupakan hal penting yang dijadikan dasar dalam penentuan kapasitas dalam upaya memenuhi permintaan. Pada penelitian ini dikembangkan sebuah model pelayanan bongkar muat general kargo di Pelabuhan Tanjung Perak yang mampu memperkirakan jumlah permintaan dan perencanaan kapasitas bongkar muat sesuai dengan strategi perencanaan kapasitas dengan pendekatan sistem dinamik. Hasil penelitian ini menunjukkan bahwa kombinasi produktivitas dan lead time bisa digunakan sebagai dasar pengambilan keputusan dalam perencanaan kapasitas dan model sistem dinamik bisa digunakan untuk memperkirakan permintaan dan pengembangan skenario yang flexible dalam perencanaan kapasitas.

Kata kunci: perkiraan, permintaan, perencanaan kapasitas, sistem dinamik

\section{PENDAHULUAN}

Indonesia yang memiliki karakteristik wilayah yang didominasi oleh laut dan pulau. Luas wilayah kelautan mencapai $3.257 .483 \mathrm{~km} 2$ dan jumlah pulaunya mencapai lebih dari 13.46 buah (BIG, 2010). Posisi Indonesia yang sangat strategi yakni berada pada jalur dua benua yakni benua Asia dan Australia serta dua samudra yaitu samudra Hindia dan Pasifik yang menjadi jalur perdagangan international. Menurut data dari Badan Pusat Statistik (BPS) tahun 2012 volume ekspor Indonesia mencapai 600.137 ribu ton atau senilai \$US 190.032 juta, sedangkan untuk valume impor mencapai 136.373 ribu ton atau senilai \$US 191.691 juta. Dalam sepuluh tahun terakhir volume ekspor selalu meningkat rata-rata 42.286 ribu ton, sedangkan untuk nilai ekspor umumnya meningkat rata-rata \$US 14.330 juta kecuali pada tahun 2009 dan 2012 .
Untuk volume import umumnya meningkat ratarata 7.408 ribu ton sedangkan untuk nilai import umumnya meningkat yakni rata-rata \$US 17.682 juta kecuali pada tahun 2009. Jumlah bongkar muat barang yang terjadi di pelabuhan Indonesia yang terjadi pada tahun 2011 mencapai 978.720 ribu ton yang terdiri dari 376.652 ribu ton untuk muat barang ke luar negeri (export) sedangkan untuk bongkar barang dari luar negeri (import) mencapai 78.836 ribu ton. Untuk muat barang antar pulau mencapai 238.940 ribu ton sedangkan untuk bongkar barang antar pulai mencapai 284.292 ribu ton. Dari data-data tersebut terlihat bahwa sebagian besar barang yang dikirim baik ekspor, impor dan antar pulau di Indonesia dilakukan melalui pelabuhan artinya sarana transportasi yang digunakan adalah transportasi laut yakni melalui kapal laut. 
Kegiatan supply chain diawali dari permintaan barang atau jasa, dari permintaan tersebut penentuan strategi ditentukan dalam upaya memenuhi permintaan tersebut (Pujawan \& Mahendrawati, 2010). Dengan mengetahui jumlah permintaan di masa yang akan datang produsen bisa menentukan kapasitas produksi yang dibutuhkan untuk memenuhi permintaaan. Untuk mengetahui jumlah permintaan di masa yang akan datang bisa dilakukan dengan cara meramalkan permintaan tersebut, menurut Makridakis dkk, 1998, peramalan adalah perkiraan nilai-nilai sebuah variabel berdasarkan nilai yang diketahui dari variabel tersebut atau variabel lain. Tujuan akhir dari aktivitas ini adalah untuk meningkatkan angka penjualan produk/layanan sehingga berdampak pada peningkatan pendapatan perusahaan serta menekan waktu yang diperlukan untuk memenuhi permintaan produk/layanan yang diinginkan oleh pelanggan.

North Carolina State University(NCSU) (2011) mendefinisikan kapasitas planning secara sederhana yaitu sebuah proses penentuan jumlah kapasitas yang dibutuhkan yang akan dipenuhi di masa akan datang. Ketika melakukan perencanaan kapasitas harus diperhatikan keseimbangan antara jumlah permintaan dan utilisasi dari kapasitas, untuk menyeimbangan kedua hal tersebut dibutuhkan strategi. Dalam penentuan kapasitas yang diperlukan terdapat tiga strategi yang umum biasanya digunakan Vlachos dkk, (2007), yaitu (1) Leading Capacity, (2)Trailing capacity (3) dan Matching.



PT. Pelindo III adalah Badan Usaha Milik Negara (BUMN) dengan bidang usaha sektor perhubungan, perusahaan ini didirikan pada tahun 1960 yang tertuang pada PP no. 19 tahun 1960. Perusahaan ini mempunyai tanggung jawab mengelola pelabuhan umum di tujuh wilayah propinsi Indonesia, yaitu Jawa Timur, Jawa Tengah, Bali, Kalimantan Selatan, Kalimantan Tengah, Nusa Tenggara Barat dan
Nusa Tenggara Timur. Berdasarkan UU no. 17 tahun 2008 tentang Pelayaran dan dikuatkan oleh Surat dari Kementrian Perhubungan melalui Dirjen Perhubungan Laut nomor KP88 yang diterbitkan bulan februari 2011, perusahaan ini berwenang sebagai pengelola dan pelaksana terminal di wilayah kerja tersebut, salah satu pelayanannya adalah Penyediaan dan/atau pelayanan jasa dermaga untuk pelaksanaan kegiatan bongkar muat barang dan peti kemas.

Sistem Pengambilan Keputusan (SPK) merupakan sebuah sistem informasi berbasis komputer digunakan dalam pengambilan keputusan pada sebuah organisasi, karakteristik dari SPK menurut Sprague (1980) adalah menggabungkan penggunaan model atau teknik analisa dengan data atau fungsi pencarian informasi dan fleksibelitas dan adaptasi yang tinggi untuk mengakomodasi perubahan pada lingkungan sekitar. Salah satu bidang ilmu dari SPK menurut Power (2002) adalah model-driven DSS yang menekan pada akses dan manipulasi dari statistik, keuangan, optimasi dan model simulasi, model-driven DSS menggunakan data dan parameter/variabel yang disediakan oleh pengguna untuk membantu para pengambil keputusan dalam menganalisa situasi di sekitar organisasi, parameter tersebut bisa dari internal atau eksternal.

Simulasi yang mempunyai kemampuan dalam fleksibelitas dalam merekayasa sistem yang sedang berjalan dengan biaya yang lebih rendah akan lebih tepat digunakan dalam memperkirakan permintaan general cargo (kargo) dan kebutuhan kapasitas terminal pelabuhan Tanjung Perak di masa yang akan datang. Menurut (Law \& Kelton, 1991) Simulasi merupakan teknik duplikasi proses yang terjadi pada sistem nyata, tujuannya untuk mendapatkan gambaran karakteristik dari sistem. Penggambaran sistem saat ini untuk memahami prilaku dan mengukur tingkat efektifitas dari sistem dengan menggunakan komputer sebagai alat bantu untuk menguji dengan tujuan tertentu merupakan pendekatan secara sistem dinamik, yang merupakan kerangka yang berfokus pada sistem berfikir dengan cara melakukan feed back loop serta mengambil beberapa langkah tambahan tersetruktur dan melakukan pengujian dengan menggunakan model simulasi komputer (Forrester, 1994). Dalam penelitian ini mengembangkan model sistem pelayanan bongkar muat general kargo yang mampu memperkirakan permintaan dan perencanaan kapasitas terminal bongkar muat secara optimal dengan pendekatan sistem dinamik 


\section{METODOLOGI}

Untuk mengembangkan model simulasi yang mampu menggambarkan kondisi nyata sistem pelayanan bongkar muat general kargo dengan pendekatan sistem dinamik, Sterman (2000) memberikan beberapa tahapan, yaitu:

1. Identikasi masalah, tujuan yang ingin dicapai.

2. Hipotesis dinamis, yaitu pengembangan model awal berbentuk diagram kausatik atau untuk mengetahui variabel yang berpengaruh dan bagaimana hubungan antar variabel seperti yang terdapat pada gambar 2 .

3. Formulasi, yaitu pengembangan model awal bentuk stock and flow diagram dimana pada model tersebut diterapkan formula dalam persamaan matematis, bentuknya seperti yang terdapat pada gambar 3,4,5 dan 6 .

4. Uji coba, yaitu melakukan simulasi dari model yang sudah dikembangkan, simulasi model dasar dilakukan selama 12 tahun yakni mulai tahun 2000 sampai 2012 dengan menggunakan interval tahunan.

5. Validasi model, yaitu proses pengecekan apakah model simulasi yang dibuat sudah bisa menggambarkan kondisi nyata. Barlas (1989) melakukan pendekatan statistik untuk validasi suatu model, dengan membandingkan rata-rata dan membandingkan variasi ampli-tudo dari hasil simulasi model dengan data. Model dikatakan valid jika hasil uji perbandingan rata-rata nilainya kurang dari atau sama dengan 5\% dan hasil dari perbandingan variasi amplitudo nilainya kurang dari atau sama dengan $30 \%$.

6. Penerapan dan evaluasi, model yang sudah valid bisa digunakan untuk mengevaluasi kinerja dari sistem yang sedang berjalan, serta pemanfaatan model yang dikembangkan untuk memperkirakan permintaan arus kargo di masa yang akan datang dan selanjutnya dianalisa dan dievaluasi lebih lanjut.

7. Pengembangan skenario, yakni pembuatan skenario sesuai kebutuhan dalam upaya mencari solusi dari masalah yang ingin diselesaikan.

\subsection{Sub Model Arus Barang}

Sub model ini digunakan untuk memperkirakan jumlah arus kargo yang akan melalui pelabuhan tanjung perak, arus kargo dikelompokkan berdasarkan tujuan cargo yang masuk ke pelabuhan, yakni kargo international yang terdiri dari kargo tujuan eksport dan kargo yang berasal dari import, kelompok kargo lainnya adalah kargo domestik yang terdiri dari kargo muat (loading cargo) dan kargo bongkar (discharging cargo) seperti yang terdapat pada gambar 2. Dari submodel ini nantinya akan digunakan untuk memperkirakan jumlah kargo yang akan melalui pelabuhan di masa yang akan datang (demand).
Dengan mengetahui perkiraan permintaan yang akan datang, pihak pelabuhan bisa memperkirakan berapa kapasitas dermaga yang harus disiapkan, sehingga kinerja operational bongkar muat di dermaga bisa optimal, untuk menghindari penumpukan barang di pelabuhan sehingga bisa ditekan seoptimal mungkin.

\subsection{Sub Model Kapasitas Produksi}

Sub model ini menggambarkan kapasitas produksi yang dimiliki oleh pelabuhan tanjung perak seperti pada gambar 3. Kapasitas produksi merupakan kemampuan yang dimiliki pelabuhan untuk melakukan proses bongkar/muat barang dari atau menuju kapal yang berlabuh baik yang jenis kargo atau petikemas. Untuk menghitung kapasitas produksi pada sub model ini mengadopsi perhitungan Port Development yang keluarkan oleh (UNCTAD, 1985), yaitu:

$$
\text { Capacity }=24 x C \times T \times r
$$

Capacity bongkar/muat kargo (ton/tahun), 24 adalah jumlah jam per hari, $C$ adalah rata-rata kapasitas bongkar per gank, $T$ adalah rata-rata jumlah gank yang digunakan per kapal/dermaga, $r$ adalah rasio jam kerja waktu berlabuh. Perhitungan kapasitas produksi berdasarkan jenis kemasan barang dan tujuan pengiriman barang yaitu Handling capacity of Gangs (Domestic) dan Handling capacity of Gangs (International).

\subsection{Sub Model Arus Kapal}

Gambar 5 merupakan sub model arus kapal yang datang ke pelabuhan tanjung perak yang terdiri dari dua kenis kapal, yaitu kapal kargo. Selain model arus kapal, juga terdapat model Gross Tonnage (GT) untuk kapal kargo, GT merupakan perhitungan kapasitas kapal yang terdapat dibawah dan diatas geladak kapal, GT kapal menggunakan satuan ton, yaitu satuan berat untuk ukuran besar.

\subsection{Sub Model Pelayanan Cargo}

Gambar 6 adalah merupakan model utama dalam penelitian ini, yakni model pelayanan bongkar muat kargo, model ini menyelaraskan permintaan (demand) dan kapasitas (supply), dengan tujuan untuk menghindari penumpukan barang (back$\log$ ) di dermaga. Demand terdiri dari arus kargo tujuan international (International Cargo Traffic) dan domestic (Domestic Cargo Traffic), sedangkan pada model ini juga digunakan untuk menganalisa produktivitas gang di dermaga tanjung perak, variabel yang digunakan untuk menganalisa kekurangan kapasitas (shortage capacity) yang terjadi. Analisa lainnya adalah lead time dari proses supply barang, yakni penundaan (delay) pemenuhan permintaan bongkar muat barang, akibat keterbatasan atau kekurangan kapasitas bongkar muat yang dimiliki. 
Maulidi, dkk., Perencanaan Kapasitas Terminal General Cargo dengan Pendekatan Sistem Dinamik
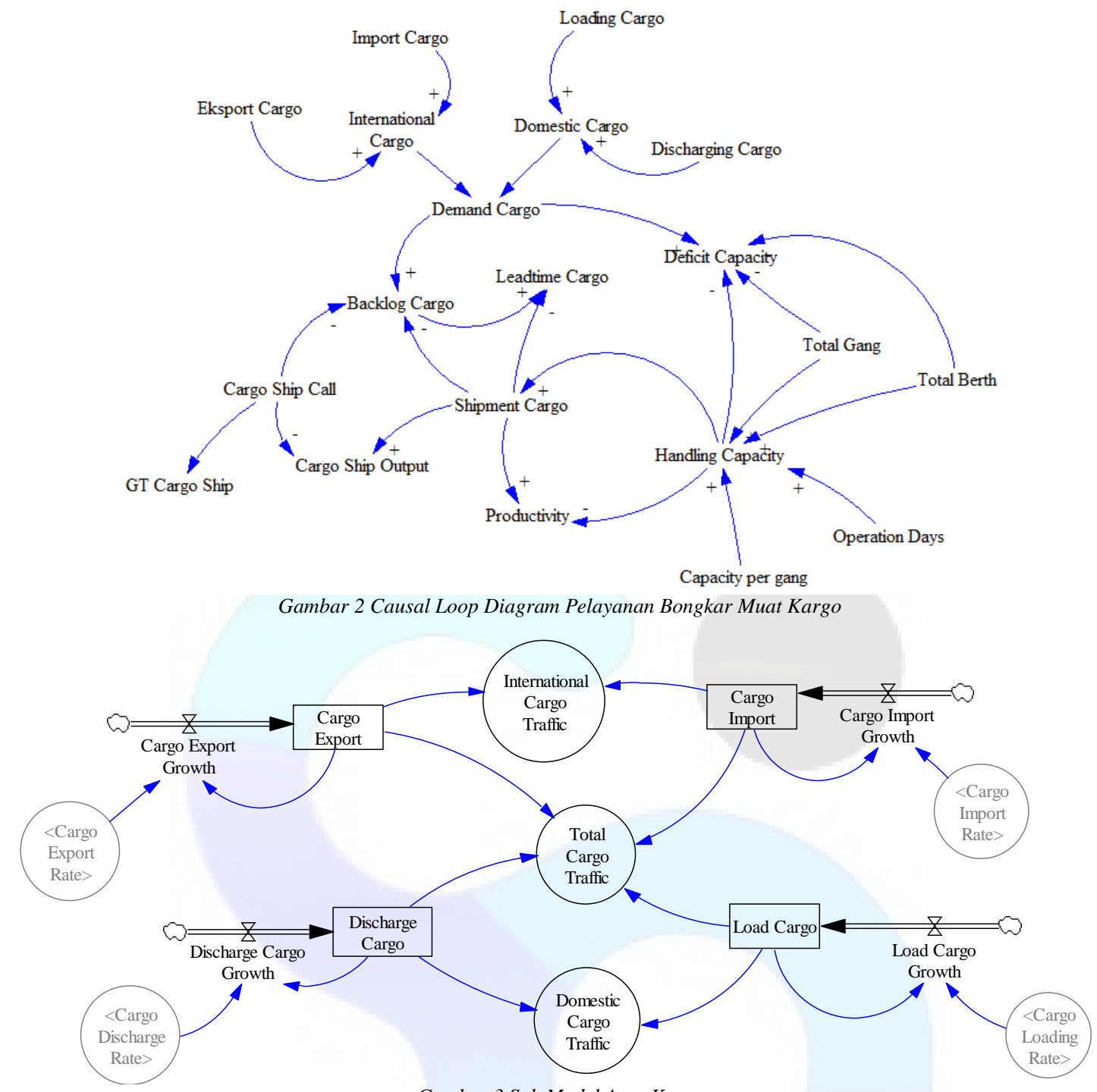

Gambar 3 Sub Model Arus Kargo

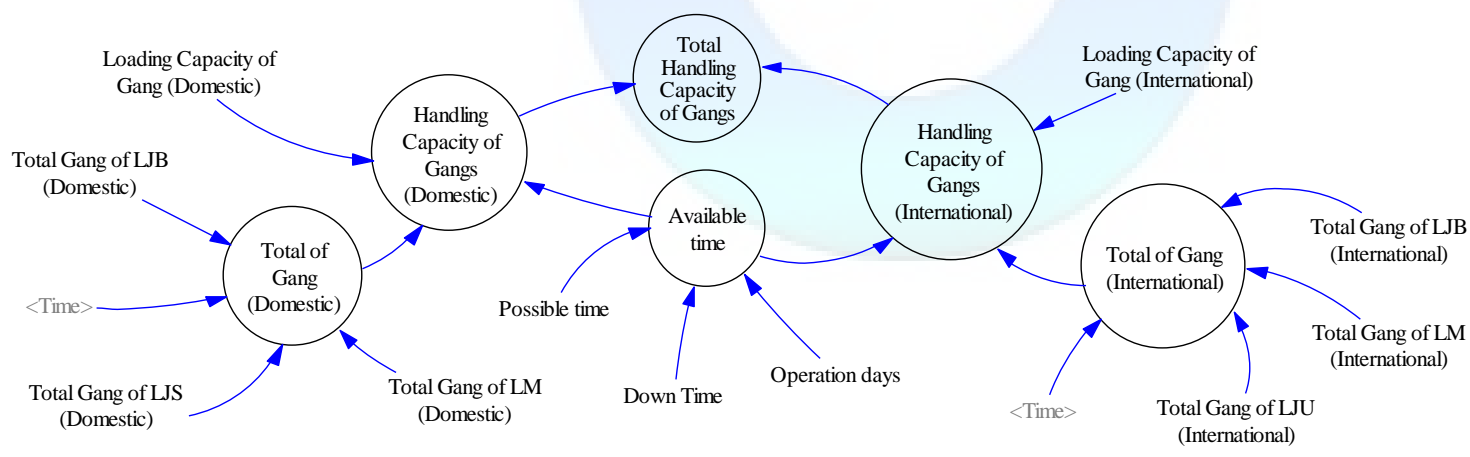

Gambar 4 Sub Model Kapasitas Produksi

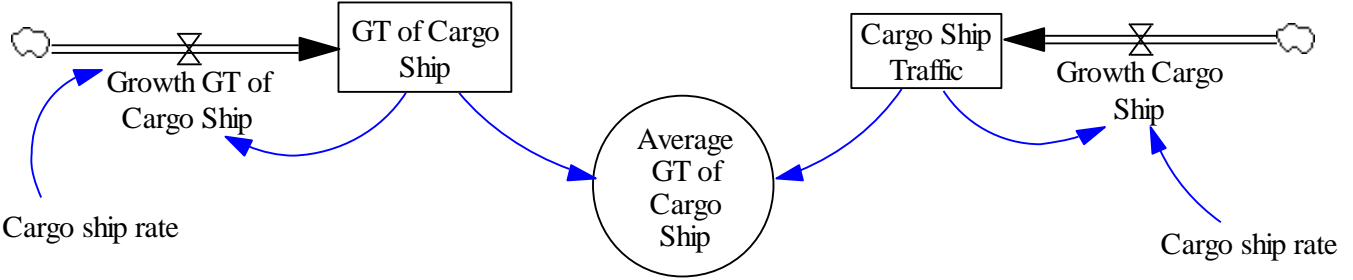

Gambar 5 Sub Model Arus Kapal 


\subsection{Simulasi dan Validasi Model}

Gambar 7 adalah Perbandingan arus kargo international hasil simulasi dengan data, proses selanjutnya adalah melakukan validasi dengan cara melakukan uji statistik. Hasil uji perbandingan ratarata antara hasil simulasi dengan data arus kargo international adalah sebagai berikut:

$$
E_{1} \text { Cargo International }=\frac{|5,712,065-5,591,023|}{5,591,023}
$$

$E_{1}$ Cargo International $=0.02$

Rata-rata arus kargo international hasil dari simulasi 5,712,065, sedangkan rata-rata data adalah 5,591,023, jika dibandingkan kedua nilai tersebut hasilnya adalah 0.0216 atau $2.16 \%$ kurang dari $5 \%$. Hasil uji perbandingan variasi amplitude antara hasil simulasi dengan data arus kargo international adalah sebagai berikut:

$$
\begin{gathered}
E_{2} \text { Cargo International }=\frac{|1,019,595-949,793|}{949,793} \\
E_{2} \text { Cargo International }=0.0735
\end{gathered}
$$

Nilai standar deviasi arus kargo international hasil dari simulasi 1,019,595 sedangkan rata-rata data adalah 949,793, jika dibandingkan kedua nilai tersebut hasilnya adalah 0.0735 atau $7.35 \%$ kurang dari $30 \%$, bisa disimpulkan model arus cargo international adalah valid, karena nilai $\mathrm{E}_{1}$ dan $\mathrm{E}_{2}$ masih dibawah ambang batas, yakni $5 \%$ dan $30 \%$.

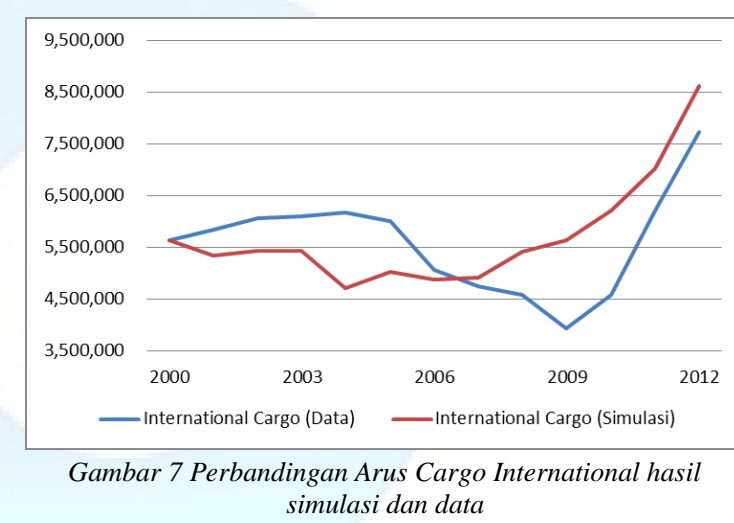

Gambar 8 adalah hasil perbandingan aruk kargo domestik hasil dari simulasi dan data, validasi model dengan membandingkan nilai rata-rata dari hasil simulasi dengan data adalah sebagai berikut:

$$
\begin{gathered}
E_{1} \text { Cargo Domestik }=\frac{|3,400,448-3,387,662|}{3,387,662} \\
E_{1} \text { Cargo Domestik }=\begin{array}{c}
0.0038
\end{array}
\end{gathered}
$$

Sedangkan hasil uji perbandingan variasi amplitude antara hasil simulasi dengan data histori dari arus kargo international adalah sebagai berikut:

$$
\begin{gathered}
E_{2} \text { Cargo Domestik }=\frac{|1,122,986-1,089,723|}{1,089,723} \\
E_{2} \text { Cargo Domestik }=\begin{array}{c}
0.0305
\end{array}
\end{gathered}
$$


Dari pengujian yang dilakukan menunjukkan bahwa nilai dari $\mathrm{E}_{1}$ dari cargo domestik adalah 0.0038 atau $0.38 \%$ masih dibawah ambang batas yakni $5 \%$, sedangkan hasil $\mathrm{E}_{2}$ dari cargo domestik adalah 0.035 atau $3.05 \%$ masih dibawah ambang batas yakni sebesar 30\%, bisa disimpulkan model arus cargo international yang sudah dikembangkan adalah valid.



Gambar 8 Perbandingan Arus Cargo Domestic hasil simulasi dan data

Gambar 9 adalah hasil simulasi kapasitas produksi dari gang untuk tujuan international dan domestik dari model yang dikembangkan dengan menerapkan persamaan penghitungan kapasitas dari UNCTAD, sampai tahun 2012 total kapasitas bongkar muat untuk kargo domestik mencapai 5,92 juta ton, sedangkan kapasitas bongkar muat kargo international mencapai 5,86 juta ton.

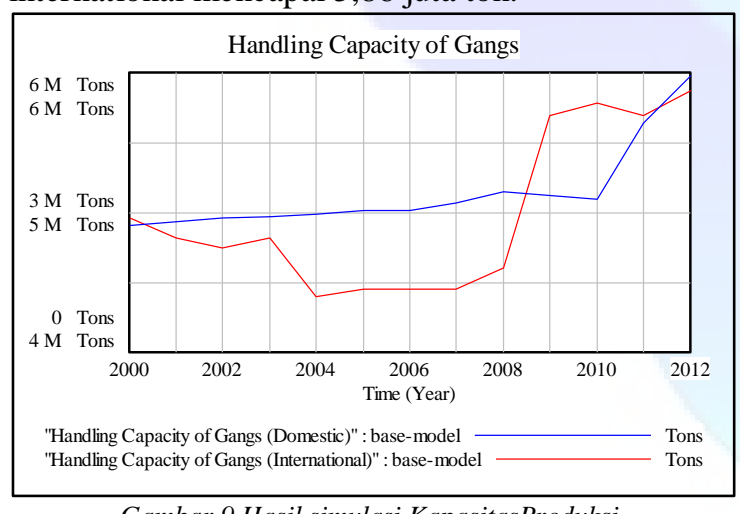

Gambar 9 Hasil simulasi KapasitasProduksi

Gambar 10 adalah perbandingan hasil total produksi bongkar muat hasil dari simulasi dengan data, hasil uji perbandingan nilai rata-rata dari hasil simulasi dengan data adalah sebagai berikut:

$$
\begin{gathered}
E_{1} \text { Produksi }=\frac{|8,097,021-8,031,096|}{8,031,096} \\
E_{1} \text { Produksi }=0.008
\end{gathered}
$$

Sedangkan hasil uji perbandingan variasi amplitude antara hasil simulasi dengan data histori produksi bongkar muat kargo adalah sebagai berikut

$$
\begin{gathered}
E_{2} \text { Produksi }=\frac{|1,398,954-1,311,270|}{1,311,270} \\
E_{2} \text { Produksi }=\quad 0.067
\end{gathered}
$$

Hasil validasi menunjukkan bahwa nilai E1 Produksi adalah 0.0082 atau $0.08 \%$ masih dibawah $5 \%$, sedangkan nilai E2 produksi adalah 0.669 atau 6.69 masih bawah ambang batas yakni 30\%, bisa disumpulkan bahwa model tersebut valid.

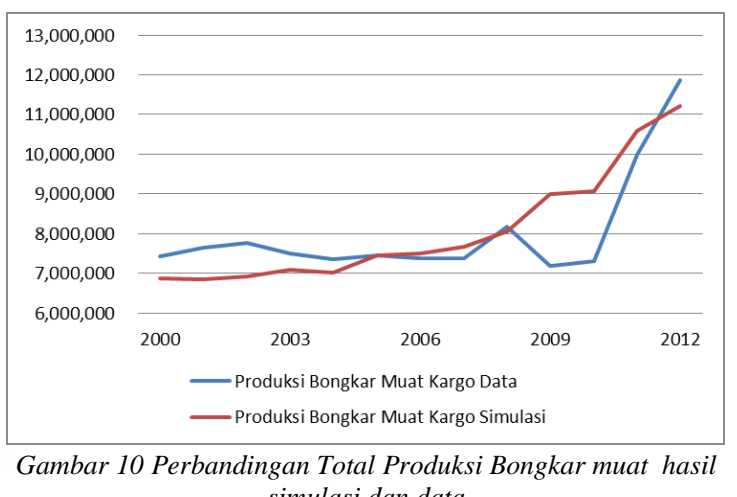
simulasi dan data

\section{HASIL DAN PEMBAHASAN}

Gambar 11 adalah hasil perbandingan antara demand dan kapasitas kargo hasil dari simulasi model dasar yang sudah divalidasi, terlihat pada tahun 2005 kapasitas bongkar muat(Total Handling Capacity) yang dimiliki sudah jauh lebih kecil jika dibandingkan dengan arus cargo(Total cargo traffic) yang masuk, sehingga mengakibatkan penumpukan cargo(Total Backlog Cargo) terus bertambah, sampai tahun 2012 jumlahnya mencapai 10.46 juta ton. Selisih antara jumlah arus kargo dengan kapasitas yang dimiliki mulai tahun 2004 sampai 2012 semakin besar.

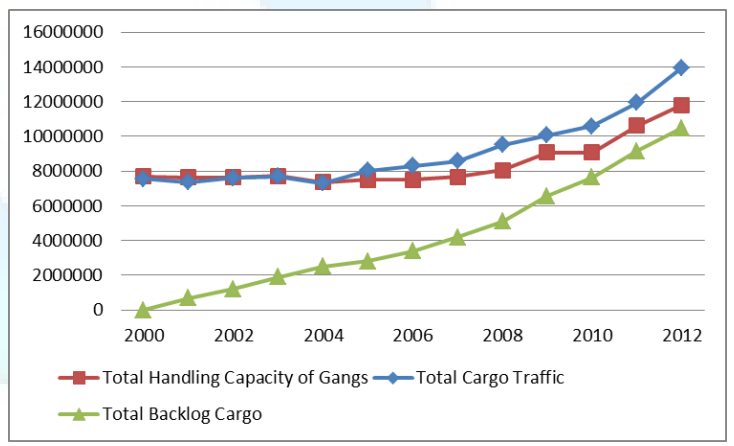

Gambar 11 Perbandingan Demand dan Kapasitas Kargo

Gambar 12 adalah hasil simulasi dari model yang sudah dikembangkan, yaitu perkiraan arus kargo(demand) dan perkiraan penumpukan kargo(backlog) tahun 2032, jika diasumsikan dalam 20 tahun kedepan tidak terjadi penambahan kapasitas. Diperkirakan pada tahun 2032 arus cargo akan mencapai 62.62 juta ton atau meningkat ratarata sebesar $7.8 \%$ per tahun, sedangkan jumlah backlog akan mencapai 369 juta ton atau meningkat rata-rata sebesar $19.6 \%$ per tahun. 


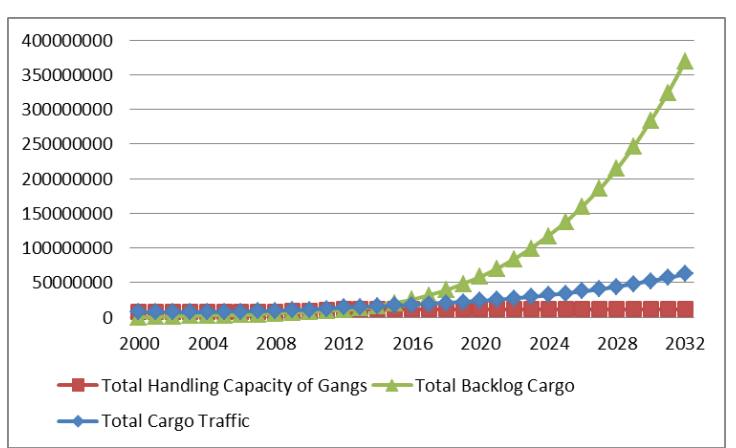

Gambar 12 Perkiraan Arus Cargo dan Backlog Kargo

Untuk menekan jumlah penumpukan barang di pelabuhan, pengelola pelabuhan disarankan membuat perencanaan untuk penambahan kapasitas bongkar muat kargo, penambahan kapasitas menurut Heizer dan Render(2006) termasuk dalam long-range planning, dalam perencanaan penambahan kapasitas ditentukan oleh strategi yang digunakan. Pengembangan skenario dalam upaya untuk memenuhi permintaan yang terus meningkat, sehingga diharapkan bisa mengurangi penumpukan kargo yang berada di pelabuhan tanjung perak dan tingkat produktivitas pekerja bisa mencapai rata-rata sekitar $80 \%$.

Dalam perencanaan kapasitas CDC (2008) memberikan panduan langkah-langkah dalam perencanaan kapasitas, yaitu:

a. Menentukan kebutuhan kapasitas

b. Menganalisa kapasitas yang dimiliki

c. Membuat rencana kapasitas ke depan

Skenario yang dilakukan dengan cara melakukan perubahan struktur model yakni mengembangkan sebuah model untuk mengambil keputusan kapan waktu yang tepat untuk menambahkan kapasitas yakni dengan menambah sejumlah kelompok pekerja yang diperlukan agar tujuan yang ingin dicapai terpenuhi. Dalam skenario ini yang menjadi dasar pertimbangan untuk pengambil keputusan untuk penambahan kapasitas adalah produktivitas dari gang(pekerja), lead time dari pelayanan dan tipe strategi yang pilih. Tipe strategi yang dipilih akan menentukan nilai ambang batas dari lead time (LEAD TIME THRESHOLD) dan ambang batas produktivitas (LEAD TIME THRESHOLD). Secara sederhana proses dari model pengambil keputusan pada gambar 13 tersaji dalam bentuk algoritma berikut:



Stack and flow yang dikembangkan memungkinkan untuk menentukan strategi capacity planning yang ingin digunakan, yakni dengan cara mengubah nilai dari variable type planning dengan nilai 1 untuk strategi leading capacity, 2 untuk strategi matching capacity dan 3 untuk strategi trailing capacity Gambar 14 adalah hasil dari skenario yang dilakukan, yakni penambahan kapasitas bongkar muat kargo, penambahan kapasitas terjadi sebanyak enam kali sepanjang tahun 2013 sampai 2032, dengan rata-rata kenaikannya adalah sekitar $70 \%$ jika dibandingkan kapasitas tahun sebelumnya, total penambahan sampai akhir periode simulasi mencapai 124,85 juta juta ton dengan rinciaan penambahan 94,25 juta ton untuk kapasitas bongkar muat kargo domestik dan 40,59 juta ton untuk penambahan kapasitas bongkar muat kargo international. Penambahan kapasitas paling besar terjadi pada tahun 2031 sejumlah 21,16 juta ton dan penambahan kapasitas terkecil terjadi pada tahun 2021 sejumlah 7,19 juta ton.

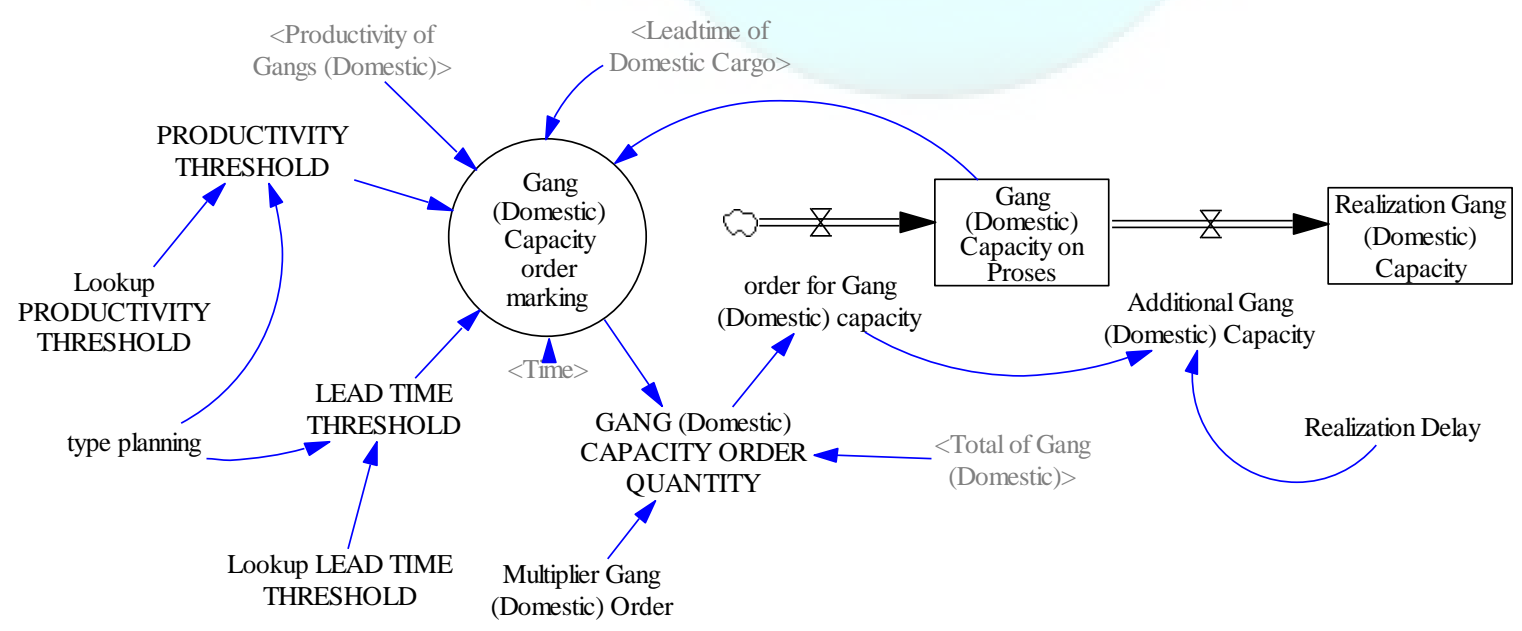

Gambar 13 Stock and Flow Skenario Perencanaan Penambahan Kapasitas 


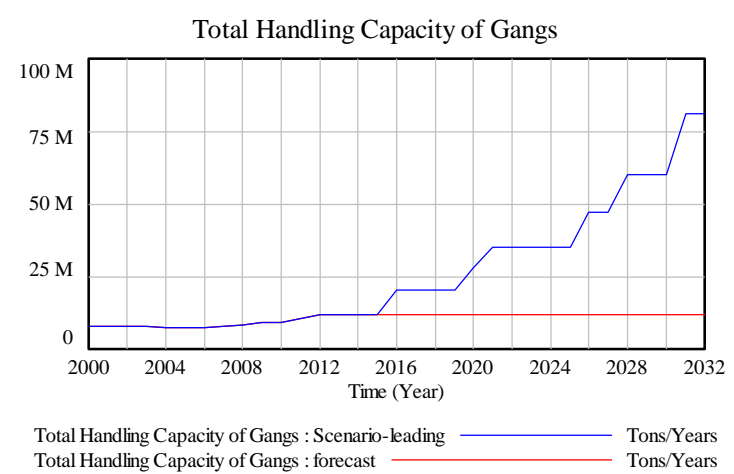

Gambar 14 Hasil Skenario Penambahan Kapasitas

Gambar 15 merupakan grafik dampak dari penambahan kapasitas bongkar muat barang yakni menyebabkan kenaikan jumlah produksi bongkar muat kargo(shipment), rata-rata kenaikannya mencapai 2,57 juta ton per tahun, sampai tahun 2032 total shipment hasil dari skenario mencapai 62,62 juta ton, jauh diatas hasil dari base mode, total shipmentnya dari base model sampai tahun 2032 mencapai 11,79 juta ton.

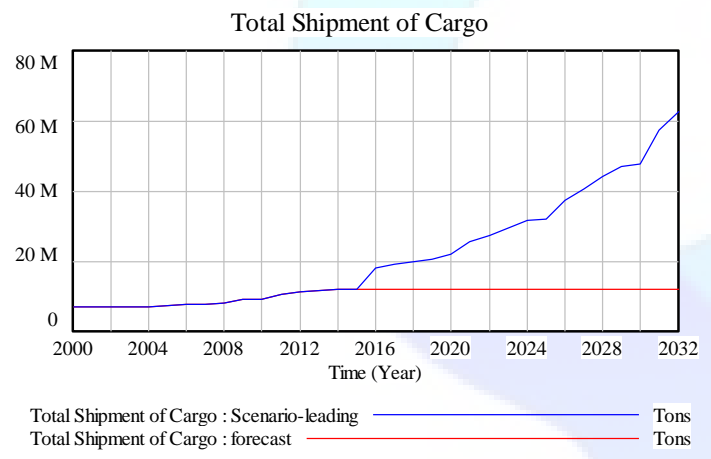

Gambar 15 Dampak Skenario terhadap Produksi bongkar muat kargo

Gambar 16 merupakan grafik dampak dari skenario terhadap penurunan tumpukan(backlog) kargo, terlihat terjadi penurunan yang cukup signifikan pada backlog, sepanjang tahun 2013 sampai 2031, kenaikan jumlah backlog hasil dari skenario ratarata mencapai 1,37 juta ton per tahun, jauh lebih sedikit jika dibandingkan dari hasil base model yang mencapai 17,92 juta ton per tahun.

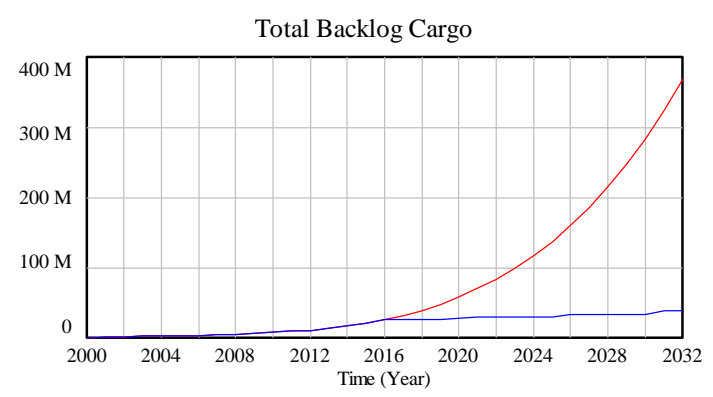

Total Backlog Cargo : Scenario-leading Total Backlog Cargo : forecast

Gambar 16 Dampak Skenario terhadap penumpukan kargo

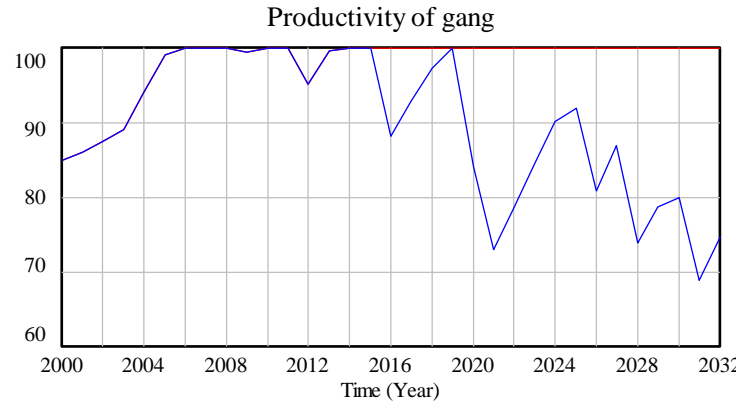

Productivity of gang : Scenario-leading Productivity of gang : forecast

Gambar 17 Dampak Skenario terhadap Produktivitas Gang

Gambar 17 merupakan grafik dampak skenario terhadap praduktifitas gang(pekerja), sepanjang tahun 2013 sampai 2032 telah terjadi penurunan produktivitas sebanyak lima kali, jumlah penurunan terbesar terjadi pada tahun 2021 yakni turun sampai $72.87 \%$ dari $100 \%$ yang dicapai pada tahun 2019 atau turun sebesar 21,13\%, jika diratarata jumlah penurunannya mencapai $13.83 \%$, sampai akhir periode simulasi yakni tahun 2031 produktivitas gang mencapai $74.77 \%$.

Selanjutnya akan dibahas perbandingan hasil skenario dengan menggunakan strategi leading capacity, matching capacity dan trailing capacity terhadap perubahan pada jumlah kapasitas bongkar muat kargo dan pada jumlah backlog kargo dalam periode tahun 2012 sampai tahun 2032.

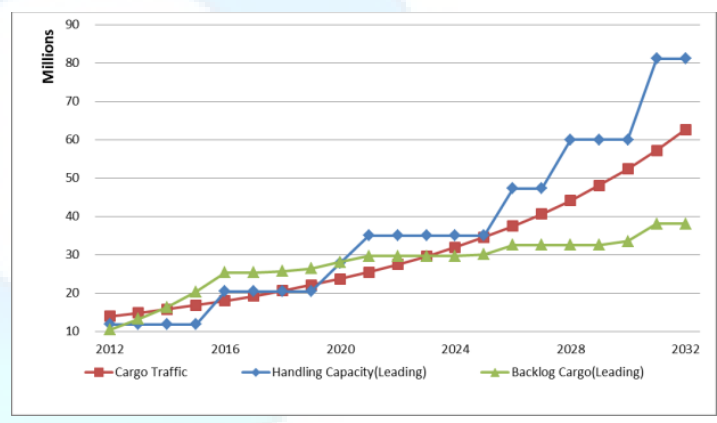

Gambar 18 Perkiraan Arus Cargo dan Backlog Kargo setelah penambahan kapasitas dengan strategi leading capacity

Gambar 18 adalah hasil perkiraan arus kargo(demand) dan penumpukan(backlog) setelah dilakukan skenario penambahan kapasitas bongkar muat kargo dengan strategi leading capacity, pada tahun 2020 kapasitas bongkar muat kargo sudah bisa melebihi jumlah arus kargo, dan terus bertambah, sampai tahun 2032 selisih antara kapasitas bongkar muat kargo dengan arus kargo mencapai $29.56 \%$ atau sekitar 18.5 juta ton, selisih tersebut merupakan cadangan kapasitas untuk mengantisipasi jika terjadi lonjakan kenaikan arus cargo diluar kondisi normal(anomaly), sampai tahun 2032 jumlah backlog diperkirakan mencapai sejumlah 38 juta ton. 
Gambar 19 adalah hasil perkiraan arus dan penumpukan kargo setelah dilakukan skenario penambahan kapasitas bongkar muat dengan menggunakan strategi matching capacity. Tahun 2013 sampai 2032 terjadi tiga kali penambahan kapasitas, yakni tahun 2021 dan 2030, sampai tahun 2032, sampai tahun 2032 kapasitas yang dimiliki mencapai 39,9 juta ton per tahun, sedangkan backlognya mencapai 80,9 juta ton. Sampai tahun 2032, selisih antara kapasitas bongkar muat dengan arus kargo mencapai hasil dari skenario dengan strategi matching capacity adalah minus 2,65 juta ton, kapasitasnya lebih kecil jika dibandingkan jumlah arus kargo.

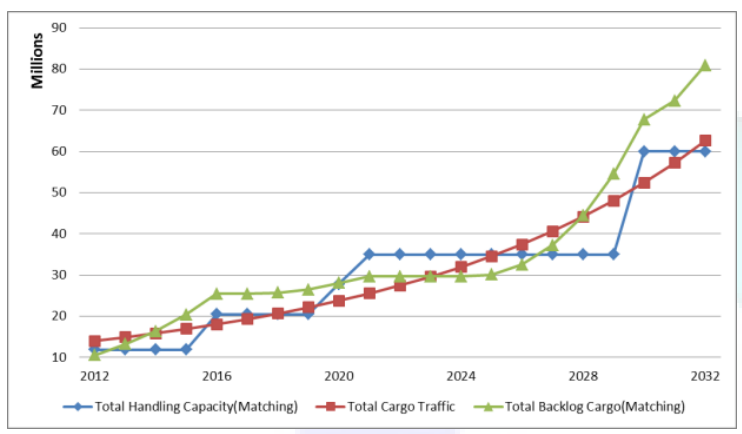

Gambar 19 Perkiraan Arus Cargo dan Backlog Kargo setelah penambahan kapasitas dengan strategi matching capacity

Gambar 20 adalah perkiraan jumlah arus dan backlog setelah dilakukan skenario penambahan kapasitas dengan strategi trailing capacity, terjadi lima kali penambahan kapasitas dalam jumlah kecil selama ahun 2012 sampai 2032, yakni pada tahun 2016, 2019, 2024, 2029 dan tahun 2031, sampai tahun 2032 kapasitas bongkar uat kargo mencapai 59,96 uta ton per tahun sedangkan tahun 2032 diperkirakan jumlah backlog kargo mencapai 106 juta ton. Sampai tahun 2032 selesih antara arus kargo dengan kapasitas bongkar muat kargo dengan menggunakan skenario strategi trailing capacity mencapai 2,65 juta ton.

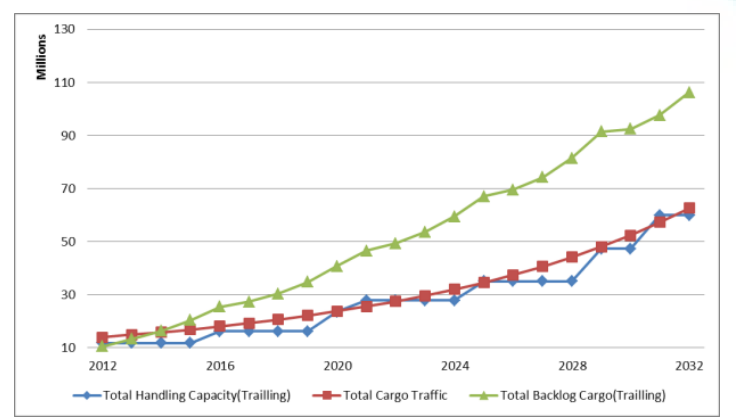

Gambar 20 Perkiraan Arus Cargo dan Backlog Kargo setelah penambahan kapasitas dengan strategi trailling capacity

\section{SIMPULAN DAN SARAN}

Pada penelitian telah dikembangkan sebuah model untuk pelayanan bongkar muat cargo di pelabuhan yang mampu untuk memperkirakan jumlah permintaan(demand) pelayanan bongkar muat kargo di pelabuhan, serta pengembangan skenario perencanaan kapasitas dengan flexible berdasarkan strategi perencanaan kapasitas yang sudah ditentukan, dalam upaya meningkatkan pelayanan dengan menekan penumpukan(backlog) kargo di pelabuhan.

Pengembangan algoritma pengambilan keputusan dalam perencanaan penambahan kapasitas bongkar muat kargo di pelabuhan dengan menjadikan kombinasi leadtime dan produktivitas layanan bongkar muat sebagai dasar pengambilan keputusan dalam penambahan kapasitas sesuai dengan strategi yang dipilih. Pengelola pelabuhan di daerah lain bisa menggunakan model yang sudah dikembangkan untuk digunakan mengevaluasi kinerja pelayanan dan kapasitas bongkar muat kargo. Penelitian ini bisa dijadikan dasar untuk pengembangan penelitian lebih lanjut dibidang pelayanan bongkar muat untuk kemasan lain misalnya untuk bulk cargo, dry cargo dll, serta analisa faktor socioeconomic yang berpengaruh kuat terhadap permintaan arus kargo.

\section{DAFTAR RUJUKAN}

Barlas, Y. (1989). Multiple test for validation of systems dynamics type of simulation models. European Journal of Operation Research, 5987.

BIG. (2010, 08 17). BIG Serahkan Peta NKRI Kepada Kemenkokesra. Dipetik 01 05, 2015, dari Badan Informasi Geospasial: http://www.bakosurtanal.go.id/berita-surta/show/bigserahkan-peta-nkri-kepada-kemenkokesra

CDC. (2008, Juni 30). Capacity Planning Practices Guide. Dipetik Desember 29, 2014, dari Centers for Disease Control and Prevention: www2a.cdc.gov/cdcup/library/practices_guid es/CDC_UP_Capacity_Planning_Practices_G uide.pdf

Forrester, J. (1994). System Dinamics, Systems Thingking, and soft OR. System Dinamics Review Summer Vol 10 No 2, 9-30.

Heizer, J., \& Render, B. (2006). Operations Management 8th Edition. New Jersey: Prentice Hall.

Law, A., \& Kelton, W. (1991). Simulation modeling and analysis. 2nd ed. New York: McGraw-Hil.

Makridakis, S., Wheelwright, S., \& Hyndman, R. (1998). Forecasting: Methods and Applications(3rd edition). John Wiley.

NCSU, N. C. (2011, 01 19). Capacity Planning. Dipetik 01 06, 2013, dari SCM ARTICLES: http://scm.ncsu.edu/scmarticles/article/capacit y-planning 
Maulidi, dkk., Perencanaan Kapasitas Terminal General Cargo dengan Pendekatan Sistem Dinamik

Power, D. (2002). Decision support systems: concepts and resources for managers. Westport: Quorum Books.

Pujawan, I. N., \& Mahendrawati, E. (2010). Supply Chain Management. Surabaya: Guna Widya.

Sprague, R. (1980). A Framework or the Development of Decision Support Systems. MIS Quarterly Vol. 4, No. 4, 1-25.

Sterman, J. D. (2000). Business Dynamics: Systems Thinking and Modeling for a Complex World. New York: Jeffrey J. Shelstad.

UNCTAD. (1985). Port Development- A handbook for planners in developing countries. Dalam Port Development- A handbook for planners in developing countries (hal. 120-124). New York: UNCTAD.

Vlachos, D., Georgiadis, P., \& Iakovou, E. (2007). A system dynamics model for dynamic capacity planning of remanufacturing in closed-loop supply chains. Computers \& Operations Research 34, 367-394.

\section{LAMPIRAN}

Table 1 Perbandingan Arus Kargo International hasil simulasi dan data

\begin{tabular}{|c|c|c|}
\hline \multirow{2}{*}{ Tahun } & \multicolumn{2}{|c|}{ International Cargo } \\
\hline & (Data) & (Simulasi) \\
\hline 2000 & $5,642,822$ & $5,642,825$ \\
\hline 2001 & $5,839,500$ & $5,341,528$ \\
\hline 2002 & $6,054,161$ & $5,430,058$ \\
\hline 2003 & $6,105,355$ & $5,432,645$ \\
\hline 2004 & $6,171,752$ & $4,708,598$ \\
\hline 2005 & $6,007,408$ & $5,034,830$ \\
\hline 2006 & $5,067,025$ & $4,884,878$ \\
\hline 2007 & $4,757,712$ & $4,909,289$ \\
\hline 2008 & $4,589,206$ & $5,413,290$ \\
\hline 2009 & $3,932,869$ & $5,629,369$ \\
\hline 2010 & $4,582,628$ & $6,205,337$ \\
\hline 2011 & $6,207,856$ & $7,018,131$ \\
\hline 2012 & $7,725,001$ & $8,606,067$ \\
\hline Rata-rata & $5,591,023$ & $5,712,065$ \\
\hline $\begin{array}{l}\text { Standar } \\
\text { Deviasi }\end{array}$ & 949,793 & $1,019,595$ \\
\hline \multicolumn{2}{|c|}{ E1 } & $2.16 \%$ \\
\hline \multicolumn{2}{|c|}{ E2 } & $7.35 \%$ \\
\hline
\end{tabular}

Table 2 Perbandingan Arus Kargo Domestik hasil simulasi dan data

\begin{tabular}{|c|c|c|}
\hline \multirow{2}{*}{ Tahun } & \multicolumn{2}{|c|}{ Domestic Cargo } \\
\cline { 2 - 3 } & (Data) & (Simulasi) \\
\hline 2000 & $1,978,926$ & $1,905,716$ \\
\hline 2001 & $2,089,373$ & $2,021,933$ \\
\hline 2002 & $2,038,343$ & $2,164,645$ \\
\hline 2003 & $2,313,370$ & $2,267,131$ \\
\hline 2004 & $2,823,364$ & $2,604,812$ \\
\hline 2005 & $3,020,052$ & $2,986,556$ \\
\hline 2006 & $3,186,879$ & $3,423,008$ \\
\hline 2007 & $3,818,084$ & $3,669,433$ \\
\hline 2008 & $4,616,068$ & $4,086,056$ \\
\hline 2009 & $4,277,822$ & $4,443,921$ \\
\hline 2010 & $3,763,950$ & $4,380,936$ \\
\hline 2011 & $4,834,000$ & $4,905,829$ \\
\hline 2012 & $5,279,379$ & $5,345,824$ \\
\hline Rata-rata & $3,387,662$ & $3,400,446$ \\
\hline Standar & $1,089,723$ & $1,122,986$ \\
\hline Deviasi & & $0.38 \%$ \\
\hline & E1 & $3.05 \%$ \\
\hline & & \\
\hline & & \\
\hline
\end{tabular}

Table 3 Perbandingan Produksi bongkar muat kargo hasil simulasi dan data

\begin{tabular}{|c|c|c|}
\hline \multirow{2}{*}{ Tahun } & \multicolumn{2}{|c|}{ Produksi Bongkar Muat Kargo } \\
\cline { 2 - 3 } & Data & Simulasi \\
\hline 2000 & $7,420,251$ & $6,869,716$ \\
\hline 2001 & $7,641,614$ & $6,839,933$ \\
\hline 2002 & $7,768,776$ & $6,909,644$ \\
\hline 2003 & $7,502,303$ & $7,085,130$ \\
\hline 2004 & $7,349,089$ & $7,005,510$ \\
\hline 2005 & $7,442,547$ & $7,439,556$ \\
\hline 2006 & $7,373,695$ & $7,504,399$ \\
\hline 2007 & $7,375,010$ & $7,664,999$ \\
\hline 2008 & $8,178,549$ & $8,051,899$ \\
\hline 2009 & $7,181,357$ & $9,001,968$ \\
\hline 2010 & $7,313,690$ & $9,073,899$ \\
\hline 2011 & $9,992,029$ & $10,599,599$ \\
\hline 2012 & $11,865,343$ & $11,215,023$ \\
\hline Rata-rata & $8,031,096$ & $8,097,021$ \\
\hline Standar & $1,311,270$ & $1,398,954$ \\
\hline Deviasi & E1 & $0.82 \%$ \\
\hline & E2 & 0.067 \\
\hline
\end{tabular}


Table 4 Perbandingan Sebelum dan Sesudah Skenario Perencanaan Kapasitas

\begin{tabular}{|c|c|c|c|c|c|c|c|c|}
\hline \multirow{2}{*}{ Tahun } & \multicolumn{4}{|c|}{ Total Capacity } & \multicolumn{4}{|c|}{ Total Backlog } \\
\hline & Forecast & Leading & Matching & Trailling & Forecast & Leading & Matching & Trailling \\
\hline 2000 & $7,694,199$ & $7,694,199$ & $7,694,199$ & $7,694,199$ & 0 & 0 & 0 & 0 \\
\hline 2001 & $7,628,499$ & $7,628,499$ & $7,628,499$ & $7,628,499$ & 678,826 & 678,826 & 678,826 & 678,826 \\
\hline 2002 & $7,631,868$ & $7,631,868$ & $7,631,868$ & $7,631,868$ & $1,202,354$ & $1,202,354$ & $1,202,354$ & $1,202,354$ \\
\hline 2003 & $7,727,385$ & $7,727,385$ & $7,727,385$ & $7,727,385$ & $1,887,412$ & $1,887,412$ & $1,887,412$ & $1,887,412$ \\
\hline 2004 & $7,354,527$ & $7,354,527$ & $7,354,527$ & $7,354,527$ & $2,502,058$ & $2,502,058$ & $2,502,058$ & $2,502,058$ \\
\hline 2005 & $7,504,399$ & $7,504,399$ & $7,504,399$ & $7,504,399$ & $2,809,958$ & $2,809,958$ & $2,809,958$ & $2,809,958$ \\
\hline 2006 & $7,504,399$ & $7,504,399$ & $7,504,399$ & $7,504,399$ & $3,391,788$ & $3,391,788$ & $3,391,788$ & $3,391,788$ \\
\hline 2007 & $7,664,999$ & $7,664,999$ & $7,664,999$ & $7,664,999$ & $4,195,275$ & $4,195,275$ & $4,195,275$ & $4,195,275$ \\
\hline 2008 & $8,051,899$ & $8,051,899$ & $8,051,899$ & $8,051,899$ & $5,108,998$ & $5,108,998$ & $5,108,998$ & $5,108,998$ \\
\hline 2009 & $9,066,599$ & $9,066,599$ & $9,066,599$ & $9,066,599$ & $6,556,445$ & $6,556,445$ & $6,556,445$ & $6,556,445$ \\
\hline 2010 & $9,073,899$ & $9,073,899$ & $9,073,899$ & $9,073,899$ & $7,627,766$ & $7,627,766$ & $7,627,766$ & $7,627,766$ \\
\hline 2011 & $10,599,599$ & $10,599,599$ & $10,599,599$ & $10,599,599$ & $9,140,140$ & $9,140,140$ & $9,140,140$ & $9,140,140$ \\
\hline 2012 & $11,796,799$ & $11,796,799$ & $11,796,799$ & $11,796,799$ & $10,464,501$ & $10,464,501$ & $10,464,501$ & $10,464,501$ \\
\hline 2013 & $11,796,799$ & $11,796,799$ & $11,796,799$ & $11,796,799$ & $13,201,368$ & $13,201,368$ & $13,201,368$ & $13,201,368$ \\
\hline 2014 & $11,796,799$ & $11,796,799$ & $11,796,799$ & $11,796,799$ & $16,297,300$ & $16,297,300$ & $16,297,300$ & $16,297,300$ \\
\hline 2015 & $11,796,799$ & $11,796,799$ & $11,796,799$ & $11,796,799$ & $20,311,814$ & $20,311,814$ & $20,311,814$ & $20,311,814$ \\
\hline 2016 & $11,796,799$ & $20,432,698$ & $20,432,698$ & $16,198,698$ & $25,376,144$ & $25,376,144$ & $25,376,144$ & $25,376,144$ \\
\hline 2017 & $11,796,799$ & $20,432,698$ & $20,432,698$ & $16,198,698$ & $31,581,820$ & $25,376,144$ & $25,376,144$ & $27,310,950$ \\
\hline 2018 & $11,796,799$ & $20,432,698$ & $20,432,698$ & $16,198,698$ & $39,030,312$ & $25,671,796$ & $25,671,796$ & $30,357,544$ \\
\hline 2019 & $11,796,799$ & $20,432,698$ & $20,432,698$ & $16,198,698$ & $47,834,264$ & $26,412,958$ & $26,412,958$ & $34,759,600$ \\
\hline 2020 & $11,796,799$ & $27,769,196$ & $27,769,196$ & $23,535,198$ & $58,118,912$ & $28,061,704$ & $28,061,704$ & $40,642,344$ \\
\hline 2021 & $11,796,799$ & $34,966,996$ & $34,966,996$ & $27,769,196$ & $70,023,664$ & $29,638,500$ & $29,638,500$ & $46,453,136$ \\
\hline 2022 & $11,796,799$ & $34,966,996$ & $34,966,996$ & $27,769,196$ & $83,703,960$ & $29,638,500$ & $29,638,500$ & $49,298,280$ \\
\hline 2023 & $11,796,799$ & $34,966,996$ & $34,966,996$ & $27,769,196$ & $99,333,272$ & $29,638,500$ & $29,638,500$ & $53,562,840$ \\
\hline 2024 & $11,796,799$ & $34,966,996$ & $34,966,996$ & $27,769,196$ & $117,105,528$ & $29,638,500$ & $29,638,500$ & $59,417,320$ \\
\hline 2025 & $11,796,799$ & $34,966,996$ & $34,966,996$ & $34,966,996$ & $137,237,728$ & $30,077,638$ & $30,077,638$ & $67,054,256$ \\
\hline 2026 & $11,796,799$ & $47,245,596$ & $34,966,996$ & $34,966,996$ & $159,972,992$ & $32,516,816$ & $32,516,816$ & $69,493,432$ \\
\hline 2027 & $11,796,799$ & $47,245,596$ & $34,966,996$ & $34,966,996$ & $185,584,064$ & $32,516,816$ & $37,202,072$ & $74,178,688$ \\
\hline 2028 & $11,796,799$ & $59,962,196$ & $34,966,996$ & $34,966,996$ & $214,377,248$ & $32,516,816$ & $44,411,792$ & $81,388,408$ \\
\hline 2029 & $11,796,799$ & $59,962,196$ & $34,966,996$ & $47,245,596$ & $246,696,800$ & $32,516,816$ & $54,461,152$ & $91,437,768$ \\
\hline 2030 & $11,796,799$ & $59,962,196$ & $59,962,196$ & $47,245,596$ & $282,930,176$ & $33,484,226$ & $67,707,160$ & $92,405,176$ \\
\hline 2031 & $11,796,799$ & $81,132,192$ & $59,962,196$ & $59,962,196$ & $323,513,792$ & $38,052,932$ & $72,275,864$ & $97,540,016$ \\
\hline 2032 & $11,796,799$ & $81,132,192$ & $59,962,196$ & $59,962,196$ & $368,939,744$ & $38,052,932$ & $80,904,728$ & $106,168,880$ \\
\hline
\end{tabular}

